JAN WNĘK* - KROSNO

\title{
POLSKIE PUBLIKACJE RELIGIJNE W OPINII KRYTYKI (1918-1939)
}

Po powrocie Polski do suwerenności państwowej znacznie ożywił się ruch wydawniczy z różnych dziedzin wiedzy. Do rąk czytelników trafiało wówczas wiele książek, które znakomicie popularyzowały najnowsze osiągnięcia naukowe, a przez to pedagogizowały odbiorców swych treści ${ }^{1}$. Nie wszystkie wydawane publikacje książkowe były napisane na odpowiednim poziomie merytorycznym. Ówcześni recenzenci nowości wydawniczych szczegółowo analizowali treść tych książek, wytykali ich autorom błędy i niedociągnięcia w prezentowaniu faktografii. Dla nas współczesnych owe recenzje stanowią ważkie źródło informacji o krytyce okresu międzywojnia.

Zainteresowanie budziły książki z zakresu religii. W latach 1918-1939 swych czytelników znajdywała literatura życia wewnętrznego, ascetyczno-mistyczna, homiletyczna a także ukazująca dzieje Kościoła. Znakomitymi propagatorami nowych prądów w życiu wewnętrznym byli m.in.: o. Jacek Woroniecki, ks. Władysław Korniłowicz, ks. Aleksander Żychliński, ks. Konstanty Michalski². W okresie II Rzeczypospolitej kształtowały się ośrodki naukowe katolickiego religioznawstwa ${ }^{3}$, zwiększał się poziom wykształcenia religijnego polskiego społeczeństwa $^{4}$, które było w zdecydowanej większości wyznania rzymsko-katolickiego. Wielu autorów dawało wyraz przekonaniu, że religia przyczynia się do formowa-

* Jan Wnęk - dr historii, adiunkt w Instytucie Humanistycznym Państwowej Szkoły Zawodowej w Krośnie.

${ }^{1}$ M. Czarnowska, Ilościowy rozwój polskiego ruchu wydawniczego 1501-1965, Warszawa 1967; N. Kraśko, Instytucje wydawnicze w II Rzeczypospolitej, Warszawa 2001.

${ }^{2}$ K. Górski, Dzieje życia wewnętrznego w Polsce, w: Księga Tysiaclecia Katolicyzmu w Polsce, t. 1. Lublin 1969, s. 378-379.

${ }^{3}$ M. Mikołajczyk, Warszawski i lwowski ośrodek katolickiego religioznawstwa w Polsce międzywojennej, Opole 1987.

${ }^{4}$ L. Grochowski, Doktryna wychowawcza katolicyzmu w Polsce międzywojennej, „Rozprawy z Dziejów Oświaty, 26 (1984) s. 173-209; Katolicka a liberalna myśl wychowawcza w Polsce w latach 1918-1939, red. E. Walewander, Lublin 2000. 
nia ładu społecznego w Polsce, umacnia jej kulturę i intelektualizm jej obywateli ${ }^{5}$.

Nakłady książek katolickich nie były wysokie, wynosiły co najwyżej 2.000 egzemplarzy ${ }^{6}$. Istotną rolę $\mathrm{w}$ tej epoce odgrywało czasopiśmiennictwo religijne, na łamach którego zamieszczano recenzje książek teologicznych. Wraz z upływem lat liczba czasopism wyraźnie wzrastała ${ }^{7}$. Najbardziej liczącymi się wówczas teologicznymi czasopismami naukowymi były periodyki o następujących tytułach: „Ateneum Kapłańskie”, „Elpis”, „Kwartalnik Teologiczny Wileński”, „Miesięcznik Katechetyczny i Wychowawczy”, „Mysterium Chrysti”, „Nowa Polonia Sacra”, „Orient”, „Polonia Sacra”, „Polski Przegląd Tomistyczny”, „Przegląd Biblijny”, „Przegląd Homiletyczny”, „Przegląd Teologiczny”, „Rocznik Teologiczny”, „Roczniki Związku Akademickich Kół Misyjnych w Polsce”, „Ruch

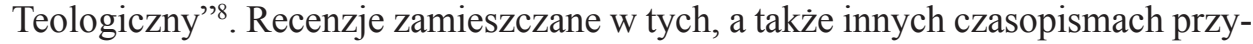
bliżały czytelnikom treść książek z zakresu religii, wskazywały na ich zalety a także braki. Autorami recenzji były osoby nie tylko duchowne ale i także świeckie.

Na polskim rynku wydawniczym dominowała literatura homiletyczna. Rozwijający się ruch rekolekcyjny sprawiał, że wydawano prace poruszające różne zagadnienia, nie tylko dotyczące życia wewnętrznego, ale i także pouczające jak należy głosić kazania, edukować wiernych. Książki o takich treściach cieszyły się znacznym powodzeniem wśród czytelników i były na ogół dobrze oceniane przez recenzentów. Z uznaniem wypowiadano się o książkach: Religia katolicka. Jej podstawy, jej źródta i jej prawdy wiary. Rozprawy dogmatyczne dla ludzi wyksztatconych Józefa Sebastiana Pelczara ${ }^{9}$ Życie nadprzyrodzone. Krótkie wzmianki nauki o środkach taski Kazimierza Naskręckiego ${ }^{10}$, Na przetęczy. Zbiór krótkich kazań i rozważań na tle ewangelii niedzielnych całego roku Nikodema Cieszyńskiego ${ }^{11}$, Na glębiach duszy, nauki rekolekcyjne dla nauczycielstwa szkót powszechnych Ildefonsa Bobicza ${ }^{12}$. Na początku omawianego okresu ukazały się Listy pasterskie, odezwy, kazania i mowy okolicznościowe arcybiskupa Józefa Bil-

${ }^{5}$ L. B. Dyczewski, Religijność społeczeństwa polskiego w okresie międzywojennym, „Collectanea Theologica” 1972, s. 32-33; M. Fabin, Miejsce i rola Kościoła w kształtowaniu ładu społecznego w Polsce, „Saeculum Christianum”, 2 (1997) s. 168.

${ }^{6}$ K. Górski, Zarys dziejów duchowości w Polsce, Kraków 1986, s. 322.

${ }^{7}$ L. B. Dyczewski, Działalność wydawnicza Kościoła Katolickiego Polsce międzywojennej, „Homo Dei”, 4 (1972) s. 293.

${ }^{8}$ C. Lechicki, Prasa katolicka w Polsce w latach 1918-1939, Warszawa 1966; Bibliografia katolickich czasopism religijnych w Polsce 1918-1945, oprac. i zestawił Z. Zieliński, Lublin 1981; G. Wrona, Polskie czasopisma naukowe w latach 1918-1939, Kraków 2005.

${ }^{9}$ J. S. Pelczar, Religia katolicka. Jej podstawy, jej źródta i jej prawdy wiary. Rozprawy dogmatyczne dla ludzi wyksztatconych, Przemyśl 1923; W. N., Recenzja, „Przegląd Homiletyczny” (dalej: PH), 2 ( 1924) s. 147-148.

${ }^{10} \mathrm{~K}$. Naskręcki, Życie nadprzyrodzone. Krótkie wzmianki nauki o środkach łaski, Warszawa 1936; T. Nawrocki, Recenzja, PH, 14 (1936) s. 280-281.

${ }^{11}$ N. Cieszyński, Na przelęczy. Zbiór krótkich kazań i rozważań na tle ewangelii niedzielnych całego roku, Poznań 1936; M. Klepacz, Recenzja, PH, 14 (1936) s. 281-282.

${ }^{12}$ I. Bobicz, Na głębiach duszy, nauki rekolekcyjne dla nauczycielstwa szkół powszechnych, Poznań 1931; M. Klepacz, Recenzja, PH, 10 (1932) s.71-72. 
czewskiego $^{13}$. Wydawnictwo to ocenił na łamach „Przeglądu Homiletycznego" ksiądz Z. Pilch. Imponowało mu opracowanie kazań, dające księżom dobry materiał do konferencji i egzort. „Kazania tego zbioru” - pisał recenzent - „są na ogół wszystkie wybitne, oryginalne. Wśród nich odznacza się treściwością, błyskami nowych myśli, poezją religijną i gorącym uczuciem kazanie na koronację obrazu M. B. Pocieszenia. Zasługuje również na uwagę kazanie o ,zasługach świętych dla narodu", posiadające cenne, głębokie i nowe myśli religijno-narodowe, miejscami bardzo silne w wyrazie uczuć. Kazanie „Maria a Najśw. Sakrament” świadczy o mistrzostwie w opracowaniu trudnych tematów, zawiera świetne refleksje myślowe. Eucharystia jako ofiara niemniej się odznacza powyższymi zaletami treści" ${ }^{\prime 4}$. Dla Pilcha ciekawe i pouczające były także zamieszczone w dziele Bilczewskiego mowy okolicznościowe.

W omawianym okresie podejmowano inicjatywy wygłaszania kazań poprzez radio. Wiele znanych osobistości dowodziło wówczas potrzeby takich audycji. Kazania radiowe wygłaszał ksiądz Michał Klepacz. Ich pokłosiem była interesująca książka Wartości życiowe religii ${ }^{15}$, zawierająca teksty siedemnastu wygłoszonych kazań ${ }^{16}$. Kaznodzieja poruszał najbardziej aktualne zagadnienia religijne, traktując o przyczynach zobojętnienia religijnego, sensie cierpienia, walce z Kościołem. Władysław Bogatkiewicz przekonywał w „Miesięczniku Katechetycznym i Wychowawczym”, że przeczytanie kazań Klepacza „sprowadza zadumę i coś jakby tęsknotę za światłem. Dużo mamy gorliwych katolików, ale mało wykształconych $\mathrm{z}$ atmosfery dzisiejszej - dużą rolę w tym wypadku odgrywa brak orientacji w rzeczach wiary, nieraz bardzo zasadniczych, brak wyrobienia myśli i zamiłowania do lektury religijnej, którą nieraz traktuje się jako pokutę, nakazaną przez spowiednika (...) Konferencje ks. Klepacza dla wielu świeckich katolików mogą być zachętą do lektury, chociażby tych książek, które autor cytuje, np. przepiękne „Dzieje Chrystusa” Papiniego, albo „Chrystus a życie ludzkie” - Foerstera"17. Bogatkiewicz dostrzegał w kazaniach Klepacza wartości pedagogiczne i religijne.

Polską literaturę teologiczną wzbogacały prace Aleksandra Żychlińskiego, jednego z liderów ruchu tomistycznego w Polsce. W 1923 roku wydano jego gruntowne dzieło Teologia - jej istota, przymioty i rozwój ${ }^{18}$, a w 1931 roku monografię pt. Życie wewnętrzne. Rozważania teologiczne ${ }^{19}$. Autor postawił sobie za cel „wyjaśnienie proste, a jednak zasadnicze, niektórych ważniejszych zagadnień życia duchownego, które grupują się około nauki teologicznej o łasce"20. Zapo-

\footnotetext{
${ }^{13}$ J. Bilczewski, Listy pasterskie, odezwy, kazania i mowy okolicznościowe, t. 2, Lwów 1922.

${ }^{14}$ Z. Pilch, Recenzja, PH, 1 (1923) s. 149-150.

${ }^{15}$ M. Klepacz, Wartości życiowe religii, Kielce-Karczówka 1936.

${ }^{16}$ H. K., Recenzja, „Ateneum Kapłańskie” (dalej: AK), 38 (1936) s. 540.

${ }^{17}$ W. Bogatkiewicz, Recenzja, „Miesięcznik Katechetyczny i Wychowawczy”, 25 (1936) s. 353 -

${ }^{18}$ A. Żychliński, Teologia - jej istota, przymioty i rozwój, Poznań 1923; O. Szrant, Recenzja, „Przegląd Teologiczny” (dalej: PT), 6 (1925) s. 96-99.

${ }^{19}$ A. Żychliński, Życie wewnętrzne. Rozważania teologiczne, Lwów 1931.

${ }^{20}$ J. Jaroszewicz, Recenzja, PH, 9 (1931) s. 315-316.
} 354. 
znawał czytelnika z podstawami teologicznej nauki o życiu wewnętrznym, wyjaśniał pojęcia natury i nadnatury, analizował rolę łaski w życiu duchownym, działanie cnót własnych i darów Ducha św. Ksiądz Jan Jaroszewicz wyraził na łamach „Przeglądu Homiletycznego” opinię, że „kaznodzieje znajdą w książce ks. Żychlińskiego nie tyle gotowy materiał do przemówień, ile gruntowny podkład teologiczny do kazań i konferencji o łasce, cnotach i darach Ducha św.”21.

W „Przeglądzie Homiletycznym” oceniono także treść książki księdza Karola Mazurkiewicza pt. Wychowanie $w$ świetle chrześcijańskiej prawdy (Hedogety$k a)^{22}$. Recenzent tego studium, ks. Michał Sopoćko zwrócił uwagę, że autor rozważa problemy pedagogiczne $\mathrm{w}$ sposób nowatorski, usiłując $\mathrm{w}$,formie prostej prawie katechizmowej - wskazać na rolę nie tylko podmiotu i przedmiotu wychowania, czyli wychowawcy i wychowanka, lecz nadto na rolę przyczyny sprawczej każdego życia, a pierwszorzędnej w wychowaniu - na rolę Stwórcy, od którego pochodzą w wychowanku siły życiowe i bez którego współudziału nie mogą się normalnie rozwijać”23. Sopoćko uważał, że praca Mazurkiewicza stanowi bardzo cenny dorobek naukowy w polskiej literaturze. Zalecał jej lekturę wychowawcom, a przede wszystkim nauczycielom, kapłanom i alumnom.

Ideały wychowania religijnego popularyzowała praca księdza Walerego Jasińskiego pt. O katolicka pedagogikę w Polsce ${ }^{24}$. Stanowiła ona ciekawe ujęcie problematyki pedagogicznej i dostarczała materiału, mogącego dać impuls czytelnikom do pogłębienia światopoglądu katolickiego. Autor rozprawy polemizował z Bogdanem Nawroczyńskim i Ludwikiem Chmajem na temat źródeł polskiej myśli pedagogicznej. W „Miesięczniku Katechetycznym i Wychowawczym” jako zaletę książki Jasińskiego wymieniano zestawienie wydawnictw polskiej pedagogiki katolickiej, uwzględnienie, obok dzieł ogólno-pedagogicznych, także prac traktujących o zagadnieniach metodyki i dydaktyki religijnej, liturgii, historiii ${ }^{25}$.

Recenzenci podkreślali walory dydaktyczne książki księdza Henryka Weryńskiego pt. Niedzielna siejba ${ }^{26}$, zawierającej liczne kazania odznaczające się potoczystością języka, żywym przekazem religijnym ${ }^{27}$. Nie szczędzono również pochwał księdzu Franciszkowi Walczyńskiemu, autorowi Podręcznika do kazań $i$ nauk o rzeczach ostatecznych ${ }^{28}$, czy też ojcu Jackowi Woronieckiemu, twórcy oryginalnych prac teologicznych ${ }^{29}$. W 1927 roku ukazała się jego rozprawa Petnia

21 Tamże

${ }^{22}$ K. Mazurkiewicz, Wychowanie w świetle chrześcijańskiej prawdy (Hedogetyka), Potulice 1938.

${ }^{23}$ M. Sopoćko, Recenzja, PH, 16 (1938) s. 280-281.

${ }^{24}$ W. Jasiński, O katolicka pedagogikę w Polsce, Katowice 1939.

${ }^{25}$ T. Kozłowski, Recenzja, „Miesięcznik Katechetyczny i Wychowawczy”, 28 (1939) s. $305-$ 307.

${ }^{26}$ H. Weryński, Niedzielna siejba, Kielce-Karczówka 1936.

${ }^{27}$ S. Sobalkowski, Recenzja, PH, 14 (1936) s. 177-179.

${ }^{28}$ F. Walczyński, Podręcznik do kazań i nauk o rzeczach ostatecznych, Tarnów 1931; S. Sobalkowski, Recenzja, PH, 9 (1931) s. 152-153.

${ }^{29}$ J. Woroniecki, Katolicka etyka wychowawcza, Poznań-Warszawa 1925; A. Borowski, Recenzja, AK, 16 (1919-1925) s. 114-118; Z. Baranowski, Recenzja, PT, 8 (1927) s. 195-197. 
modlitwy. Studium teologiczne dla inteligencji $i^{30}$. Na kartach „Ateneum Kapłańskiego" podawano, że studium Woronieckiego traktuje o doniosłych dla życia religijnego zagadnieniach, wskazuje na rolę modlitwy w uzyskiwaniu doskonałości chrześcijańskiej ${ }^{31}$. U schyłku okresu międzywojnia ukazała się praca Woronieckiego pt. Katolickość tomizmu ${ }^{32}$. Jej treść została dokładnie zanalizowana przez księdza Aleksandra Żychlińskiego. W swej recenzji zamieszczonej w „Polskim Przeglądzie Tomistycznym" reklamował procę o. Woronieckiego jako wybitne dzieło, prowadzące „do formalnego zrozumienia tomizmu" "33.

Krytycy literatury religijnej do najlepszych prac zaliczali studia księdza Konstantego Michalskiego. W 1936 roku pojawiała się na rynku księgarskim jego rozprawa pt. Nieznanemu Bogu $u^{34}$. Poruszała ona wiele zagadnień. Autor pisał o ówczesnych systemach politycznych, jak komunizm, narodowy socjalizm, ich wpływie na życie religijne i społeczne. Recenzent tego studium, ksiądz Władysław Wicher, zachwalał znakomity styl pisarski Michalskiego, ,nieraz wprost pełen polotu i wysokiego artyzmu, język filozoficzny najnowocześniejszy, skarby myśli św. Tomasza z Akwinu otwarte na oścież i to nie tylko jako vetera, ale przede wszystkim jako nova. Ten najszlachetniejszy, rasowy tomizm, który wchłaniał w geniuszu św. Tomasza wszystkie zdrowe ziarna błędnych nawet prądów, ten szlachetny, zniewalający wrogów szerokością poglądów i dobrze rozumianą tolerancją, która przekonywuje i ujmuje, a co najmniej nakaże szacunek przed chrześcijańską myślą filozoficzną, znajdziemy w tej złotej książce"35.

$\mathrm{Na}$ łamach czasopism omawiano pojawiające się na rynku wydawniczym śpiewniki kościelne oraz podręczniki dla uczniów szkół powszechnych i średnich. W 1926 roku wydano Śpiewnik kościelny z nutami i modlitewnik do użytku młodzieży szkolnej księdza Gerarda Szmyda ${ }^{36}$. Recenzent tej nowości wydawniczej, ksiądz Henryk Brzuski wyrażał w „Ateneum Kapłańskim” swoje zadowolenie z powodu ukazania się Śpiewnika, podkreślając wiele jego zalet religijno-dydaktycznych, mogących przyczynić się do rozbudzenia wśród młodzieży zamiłowania do śpiewu kościelnego, umocnienia pobożności. „Śpiewnik”- pisał recenzent - „posiada tyle zalet, że nimi podbije wszystkie dotychczas istniejące" ${ }^{37}$. Bogatą treść posiadała Etyka katolicka księdza Józefa Lubelskiego ${ }^{38}$. Praca ta była podręcznikiem przeznaczonym dla młodzieży szkół średnich, omawiała „wszystkie ważniejsze kwestie aktualne z zakresu zasad etycznych i życia etycznego, tak indywidualnego, jak i społecznego" 39 . Recenzenci dostrzegali wartości kształcące w pra-

\footnotetext{
${ }^{30}$ J. Woroniecki, Petnia modlitwy. Studium teologiczne dla inteligencji, Poznań 1927.

${ }^{31}$ H. K., Recenzja, AK, 20 (1927) s. 316-317.

32 J. Woroniecki, Katolickość tomizmu, Warszawa 1938.

${ }^{33}$ A. Żychliński, Recenzja, „Polski Przegląd Tomistyczny”, 1 (1939) s. 182-185.

${ }^{34}$ K. Michalski, Nieznanemu Bogu, Warszawa 1936.

${ }^{35}$ W. Wicher, Recenzja, AK, 38 (1936) s. 205-207.

${ }^{36}$ G. Szmyd, Śpiewnik kościelny z nutami i modlitewnik do użytku młodzieży szkolnej, Lwów-

${ }^{37}$ H. Brzuski, Recenzja, AK, 17 (1926) s. 101-102.

${ }^{38}$ J. Lubelski, Etyka katolicka, podręcznik dla szkót średnich, Tarnów 1926.

${ }^{39}$ A. Borowski, Recenzja, AK, 19 (1927) s. 86-88.
} Warszawa 1926. 
cach o charakterze katechetycznym ${ }^{40}$, duszpasterskim ${ }^{41}$, napisane językiem prostym, zrozumiałym dla czytelników ${ }^{42}$.

W dwudziestoleciu międzywojennym uczeni prowadzili badania nad łacińską hymnografią polskiego średniowiecza. Ważnym przyczynkiem do badań nad łacińską poezją kościelną w Polsce, rzucającą światło na dzieje liturgii i kultu świętych była książka księdza Bronisława Gładysza pt. Łacińskie sekwencje mszalne z polskich źródet średniowiecznych ${ }^{43}$. Oceniający w „Mysterium Christi” tą pracę uznawał ją za ciekawą i godną „najszerszego rozpowszechnienia”: „Sekwencje nasze mają często zabarwienie narodowe czy też lokalne, co świadczy o umiłowaniu Ojczyzny, której hymnografowie polscy starali się w ten sposób przysporzyć chwały (...) Wielką jest zatem zasługą czcigodnego Autora, że nam dał tak ważny przyczynek do tych badań nad łacińską poezją kościelną w Polsce"44. Praca Eacińskie sekwencje mszalne wnosiła nowe ustalenia, ugruntowywała polską wiedzę o łacińskich hymnach kościelnych.

W okresie międzywojnia sporą aktywność naukową wykazywali bibliści. Spod ich pióra wyszły liczne prace, zgłębiające wiedzę na temat ksiąg Starego i Nowego Testamentu. Ich treść była szczegółowo omawiana przez specjalistów. Wartości twórcze dostrzegano w takich pracach jak np. Uzdrowienie ślepych w Jeryho Jana Stępnia ${ }^{45}$, Maria Magdalena $w$ ewangeliach Władysława Hozakowskiego ${ }^{46}$, Poselstwo św. Jana Chrzciciela do Chrystusa w świetle historii egzegezy $i$ krytyki biblijnej Piotra Stacha ${ }^{47}$, Zstapienie do piekiet Chrystusa Pana wedle nauki św. Piotra Apostoła Seweryna Kowalskiego ${ }^{48}$. Za jednego z najlepszych znawców Bibliiuchodziłksiądz JózefArchutowski, autor licznych prac ${ }^{49}$. W „Kwartalniku Teologicznym Wileńskim" stwierdzano, że prace Archutowskiego odznaczają się jasnością wykładu, „wszechstronnym traktowaniem rzeczy”, a przy tym dostarczają polskim czytelnikom „wiele materiału nowego, całkiem jeszcze nieznanego w naszej literaturze" ${ }^{\circ 0}$.

${ }^{40}$ J. Szukalski, Katechezy dla wyższych oddziatów szkoły powszechnej, Potulice 1934; K. Werbel, Recenzja, AK, 35 (1935) s. 516-517.

${ }^{41}$ J. Winkowski, Praktyczny podręcznik duszpasterstwa w szkole średniej, Zakopane 1927; H. K., Recenzja, AK, 20 (1927) s. 426-427.

${ }^{42}$ F. Trombała, Msza św. „Rorate” czyli uroczysta wotywa o Najświętszej Maryi Pannie w adwencie. Recytacja i śpiew tekstów liturgicznych, Cieszyn 1937; R. Binnek, Recenzja, „Mysterium Christi”, 9 (1937-1938) s. 95.

${ }^{43}$ B. Gładysz, Lacińskie sekwencje mszalne z polskich źródeł średniowiecznych, Włocławek 1937.

${ }^{44}$ SMR, Recenzja, „Mysterium Christi”, 10 (1938/1939) s. 143-144.

${ }^{45}$ J. Stępień, Uzdrowienie ślepych w Jeryho, Warszawa 1936; P. Stach, Recenzja, „Przegląd Biblijny", 2 (1938) s. 95-99.

${ }^{46}$ W. Hozakowski, Maria Magdalena w ewangeliach, Lwów 1925; E. Górski, Recenzja, AK, 17 (1926) s. 311-312.

${ }^{47}$ P. Stach, Poselstwo św. Jana Chrzciciela do Chrystusa w świetle historii i krytyki biblijnej, Warszawa 1924; K. Smorowski, Recenzja, PT, 7 (1926) s. 87-89.

${ }^{48}$ S. Kowalski, Zstapienie do piekiet Chrystusa Pana wedle nauki św. Piotra Apostoła, Poznań 1928, P. Stach, Recenzja, „Collectanea Theologica”, 19 (1938) s. 250-256.

${ }^{49}$ J. Archutowski, Monoteizm izraelski i jego geneza, Kraków 1924.

${ }^{50}$ J. Kruszyński, Recenzja, „Kwartalnik Teologiczny Wileński”, 1925, s. 238-241. 
Ważną część polskiej literatury religijnej stanowiły rozprawy dotyczące dziejów Kościoła. Tematyka historyczna żywo interesowała czytelników. Na półki księgarskie trafiały prace ukazujące życie i dokonania wybitnych postaci, mocno związanych z przeszłością narodu polskiego, lub też osób, które trwale zapisały się w dziejach jakiegoś regionu. Przykładem tego typu piśmiennictwa może być książka księdza Michała Pęckowskiego o Józefie Olechowskim, archidiakonie i sufraganie krakowskim ${ }^{51}$ czy też monografia księdza Stanisława Kuźnara o świętym Andrzeju Boboli ${ }^{52}$. Ostatniej z wymienionych prac bardzo dobrą ocenę wystawił ks. Julian Humeniuk, pisząc w „Ateneum Kapłańskim”, że stanowi ona „lekturę nie tylko pobożną, lecz nadto - co nie zawsze chodzi w parze - wysoce pożyteczną i pouczającą" ${ }^{33}$. Prace poświęcone teologom polskim dawnych wieków uzyskiwały na ogół pozytywne oceny. Recenzenci zachwalali tego typu badania, wskazywali na potrzebę sukcesywnego ich rozwijania ${ }^{54}$.

Przedmiotem ocen ze strony recenzentów stała się książka księdza Józefa Umińskiego, poświęcona arcybiskupowi Henrykowi Kietliczowi ${ }^{55}$. Jej omówienia dokonał w „Przeglądzie Teologicznym” Mieczysław Niwiński, zaznaczając, że recenzowane studium wypełnia lukę w polskiej historiografii, daje „po raz pierwszy wyczerpujące opracowanie kościelnej i politycznej działalności arcybiskupa" ${ }^{156}$. Niwiński, napisanie pierwszej naukowej monografii o reformatorze Kościoła polskiego uważał, za rzecz wielkiej wagi. W niektórych fragmentach recenzowanej rozprawy dostrzegał brak obiektywizmu odnośnie oceny kościelnej i politycznej działalności Kietlicza: „(...) widzimy” - konstatował recenzent - „u ks. Umińskiego czasem pewną słabość dla swego bohatera, którego stara się oczyścić od wszelkich zarzutów, chociaż bliższe zbadanie skargi biskupa Giedki i kapituły płockiej wskazuje, że nie była ona zupełnie bezpodstawną"57. Niwiński zarzucał autorowi brak wykorzystania najnowszej literatury historycznej, jak np. prac Władysława Semkowicza, Zofii Kozłowskiej.

W okresie II Rzeczypospolitej recenzowano prace przedstawiające życie i myśl teologiczną nie tylko Polaków. W 1925 roku profesor Uniwersytetu Lubelskiego opublikował rozprawę Hierarchia kościelna u św. Augustyna, stanowiącą oryginalne studium ${ }^{58}$. Z recenzji Juliana Ogarka zamieszczonej w „Przeglądzie Teologicznym" czytelnicy tego periodyku dowiadywali się jakie problemy porusza autor. Recenzent streścił zwięźle studium Czuja, zaznaczając, że zasługą autora jest sumienność w oddaniu myśli św. Augustyna. Jako lekturę zalecał dzieło przede

${ }^{51}$ M. Pęckowski, Józef Olechowski. Archidiakon i sufragan krakowski 1735-1806. (Szkic historyczny), Kraków 1926; B. Wilanowski, Recenzja, AK, 17 (1926) s. 424-427.

${ }^{52}$ S. Kuźnar, Święty Andrzej Bobola Towarzystwa Jezusowego, Męczennik i Patron Polski, Kraków 1938.

${ }^{53}$ J. Humeniuk, Recenzja, AK, 41 (1938) s. 512-513.

${ }^{54}$ W. Wicher, X. Szymon Stanistaw Makowski, teolog moralista polski z XVII w., Kielce 1926;

H. K., Recenzja, AK, 20 (1927) s. 89-91.

${ }_{55}^{5}$ J. Umiński, Henryk arcybiskup gnieźnieński zwany Kietliczem (1199-1219), Lublin 1926.

${ }^{56}$ M. Niwiński, Recenzja, PT, 8 (1927) s. 414-417.

${ }^{57}$ Tamże.

${ }^{58}$ J. Czuj, Hierarchia kościelna u św. Augustyna, Lublin 1925. 
wszystkim dogmatykom i apologetom ${ }^{59}$. Poglądy św. Augustyna były interpretowane przez kilku polskich autorów ${ }^{60}$. Rozprawy mu poświęcone były szczegółowo omawianego przez teologów i historyków Kościoła ${ }^{61}$.

W tym samym roku co książka Czuja ukazała się rozprawa Władysława Grzelaka pt. Nauka chrystologiczna papieża Gelazego ${ }^{62}$. Głównym jej zadaniem było przedstawienie chrystologii gelezjańskiej. Autor wykazywał antiocheńskie pochodzenie chrystologii Gelazego, omawiał podobieństwa i różnice w poglądach Gelazego i Teodoreta. Ksiądz Władysław Lohn wystawił następującą ocenę studium Grzelaka: ,Rzecz gruntowna, przejrzysta, napisana według wszystkich wymóg ścisłej naukowości. Choć jestem całą duszą za jak największą ścisłością, to jednak zdaje mi się, że czcigodny autor w dążeniu do ścisłości popadł w ostateczność (...) Polski nawet „,inteligent” przestraszy się, napotykając na każdej niemal stronnicy, nie tylko w przypiskach, ale w samym tekście cytaty łacińskie, greckie, francuskie, angielskie i włoskie" 63 .

Polscy badacze dziejów duchowości chrześcijańskiej interesowali się twórczością św. Tomasza z Akwinu. Tej wybitnej postaci pracę poświęcił Andrzej Gmurowski. Nosiła ona tytuł Doskonałość chrześcijańska w myśl zasad św. Tomasza z Akwinu (Studium teologiczne) ${ }^{64}$. W czasopiśmie „Mysterium Christi” zachęcano do zapoznania się ze studium Gmurowskiego, widząc w nim ciekawą rozprawę z dziedziny teologii moralnej: „Studium O. G. oddaje wielkie usługi pogłębieniu życia liturgicznego, albowiem każdy obeznany nieco z podstawowymi prawdami życia liturgicznego po przeczytaniu książki O. G. stwierdzi z wdzięcznością, że prawdy teologii liturgicznej doznały przez studium O. G. spekulatywnego wyjaśnienia i pogłębienia. Choćby tylko wymienić prawdę o teocentryzmie życia chrześcijańskiego" ${ }^{5}$. W „Mysterium Christi” wyrażano nadzieję, że praca Doskonałość chrześcijańska przyczyni się do pogłębienia w społeczeństwie polskim zrozumienia i wartości kultury teologicznej.

Niektóre prace traktujące o historii religii spotkały się z bardzo krytycznymi ocenami ze strony recenzentów. Spośród nich można wymienić studium Jana Ptaśnika, zatytułowane Kultura wieków średnich, t. 1: Życie religijne i społecz$n e^{66}$. Autor był znanym w środowisku historycznym badaczem kultury polskiej w okresie humanizmu, a także wydawcą źródeł średniowiecznych. Swą rozprawę o średniowiecznym życiu religijnym pisał w oparciu o źródła protestanckie.

${ }^{59}$ O. Ogarek, Recenzja, PT, 7 (1926) s. 96-98.

${ }^{60}$ B. Świtalski, Neoplatonizm a etyka św. Augustyna, t. 1, Warszawa 1938; Z. Stachura, Recenzja, „Polski Przegląd Tomistyczny”, 1 (1939) s. 92-93.

${ }^{61}$ S. Abt, Św. Augustyn jako pedagog, Kraków 1930; K. Werbel, Recenzja, „Przegląd Teologiczny”, 11 (1930) s. 547-549; zob. także: J. Pastuszka, Niematerialność duszy ludzkiej u św. Augustyna, Lublin 1930; X. Stepa, Recenzja, PT, 11 (1930) s. 549-552.

${ }^{62}$ W. Grzelak, Nauka chrystologiczna papieża Gelazego I, Lwów 1925.

${ }^{63}$ W. Lohn, Recenzja, PT, 7 (1926) s. 211-212.

${ }^{64}$ A. Gmurowski, Doskonałość chrześcijańska w myśl zasad św. Tomasza z Akwinu (Studium teologiczne), Gniezno 1934.

${ }^{65}$ A. Wronka, Recenzja, „Mysterium Christi”, 5 (1933-1934) s. 190-191.

${ }^{66}$ J. Ptaśnik, Kultura wieków średnich, t. 1: Życie religijne i społeczne, Warszawa 1925. 
W „Ateneum Kapłańskim” bezpardonowo wytykano błędy, popełnione przez Ptaśnika w interpretacji dziejów życia religijnego w wiekach średnich, jak np. naiwne pojmowanie grzechu pierworodnego, Niepokalanego Poczęcia NMP, ascezy średniowiecznej, stosunku Kościoła do sakramentu małżeństwa. „Naukowej wartości zatem książka nie posiada żadnej (...) Jest ona właściwie tylko kompilacją lichszego gatunku (...) Zamiast książki, która mogłaby i powinna stać się ozdobą bibliotek polskich, dał broszurę, nadającą się na stragan i do kiosków ulicznych (...) Ogólny wniosek wypada ten: z wyżyn czystej nauki spadł prof. Ptaśnik do rzędu wprowadzonego u nas świeżo „rojowego" pamflecisty. Jest to tym przykre, że na Zachodzie zaczynają obecnie już pojmować „średniowiecze” i książka p. Ptaśnika byłaby tam w sferach prawdziwie inteligentnych nie do pomyślenia”67. Również w „Przeglądzie Teologicznym” zwracano uwagę, że książka Ptaśnika nie daje pełnego i bezstronnego obrazu życia religijnego i społecznego w okresie średniowiecza ${ }^{68}$.

Recenzenci dostrzegali błędy merytoryczne w pracy księdza Józefa Kruszyńskiego pt. Studia nad porównawcza historia religii ${ }^{69}$. Omówienia jej treści podjął się ksiądz Szczepan Szydelski, profesor Uniwersytetu Jana Kazimierza. Do wad rozprawy zaliczał nieprawidłową jej strukturę, nieścisłe używanie pojęć fillozoficzno-religijnych. Szydelski nie ograniczył się wyłącznie do wytykania braków recenzowanej przez siebie pozycji książkowej, lecz podniósł także zasługi autora: „Chciał pracą swoją służyć sprawie katolickiej, chrześcijańskiej wierze, dlatego przebija się na każdej niemal stronicy intencja apologetyczna (...) podaje bardzo wiele faktów naukowych, orientuje dobrze co do ruchu naukowego na polu studiów nad początkami religii i nad historią religii, wprowadza w te studia" ${ }^{\prime 70}$. Recenzent poczytywał za zasługę autorowi także zaznajamianie czytelnika z literaturą katolicką zagraniczną.

Pionierską pracą historyczną była książka księdza Edmunda Nowaka pt. Rys dziejów duszpasterstwa wojskowego w Polsce $968-1831^{71}$. Była to pierwsza monografia omawiająca $\mathrm{w}$ tak szerokim zakresie dzieje duszpasterstwa na ziemiach polskich. Została wydana przez Wojskowy Instytut Naukowo-Wydawniczy. Autor oparł swe rozważania na bogatym materiale źródłowym. Jak wynika z recenzji Tadeusza Glemmy, materiał ten nie zawsze został wykorzystany i zinterpretowany w sposób prawidłowy. Recenzent widział w pracy Nowaka wiele błędów: „Przede wszystkim ujął autor swój temat zbyt szeroko, pisząc obszernie o czasach, w których o właściwym duszpasterstwie wojskowym nie mogło być mowy, i nie robiąc różnicy między osobistymi kapelanami, spowiednikami lub kaznodziejami panujących czy dowódców a duszpasterzami wojskowymi (...) Razi dalej nierównomierne i niesystematyczne rozłożenie materiału opracowanego poza tym nie dość zwięźle"72. Glemma radził autorowi bardziej krytyczne ocenianie

\footnotetext{
${ }^{67}$ K. Ch., Recenzja, AK, 17 (1926) s. 315-316.

${ }^{68}$ M. Poleski, Recenzja, PT, 8 (1927) s. 76-77.

${ }^{69}$ J. Kruszyński, Studia nad porównawcza historia religii, Poznań 1926.

${ }^{70}$ S. Szydelski, Recenzja, PT, 8 (1927) s. 407-410.

${ }^{71}$ E. Nowak, Rys dziejów duszpasterstwa wojskowego w Polsce 968-1831, Warszawa 1932.

${ }^{72}$ T. Glemma, Recenzja, „Collectanea Theologica”, 15 (1934) s. 104-105.
} 
źródeł, wyzyskanie materiałów źródłowych przechowywanych w Archiwum Głównym Akt Dawnych.

Nie ulega wątpliwości, że liczne recenzje ogłaszane w specjalistycznych czasopismach okresu międzywojnia w wydatny sposób przyczyniały się do popularyzacji treści książek z zakresu religii. Nie bez znaczenia był fakt, że nowości wydawnicze omawiali najwybitniejsi ówcześni znawcy zagadnień teologicznych, którzy nie tylko zachwalali wartość merytoryczną rozpraw, ale i także karcili autorów za bylejakość pracy. Niektórzy recenzenci radzili autorom co należy zrobić, aby ich książki w kolejnych wydaniach zyskały na swej wartości naukowej, zalecali maksymalne i krytyczne wykorzystanie źródeł.

Dla nas czasopisma wydawane w okresie II Rzeczypospolitej stanowią nie do przecenienia źródło informacji o krytyce naukowej tamtych czasów. Znaczna część recenzentów bardzo poważnie traktowała swoją pracę, przekazując czytelnikom swe obiektywne opinie odnośnie ocenianych rozpraw. Ich recenzje były niekiedy obszerne, kilkustronicowe, znakomicie analizowały rozważania autorów. Spora ilość recenzji nowości wydawniczych z zakresu religii ogłoszonych w latach 1918-1939 utwierdza nas w przekonaniu, że tego typu literatura cieszyła się dużym zainteresowaniem czytelników, zarówno ze sfer inteligenckich jak i niewykształconych.

\title{
POLISH RELIGIOUS BOOKS (1918-1939) IN THE ASSESSMENT OF THE CRITICISM OF THE TIME
}

\begin{abstract}
Summary
The article shows how reviewers assessed religious books during the Second Polish Republic. Reviews were placed in a number of professional journals such as „Ateneum Kapłańskie” ("Sacerdotal Athenaeum”), „Kwartalnik Teologiczny Wileński” ("Vilnius Theological Quarterly”), „Miesięcznik Katechetyczny i Wychowawczy”(“Catechetical and Educational Magazine”), „Mysterium Chrysti”, „Polski Przegląd Tomistyczny”("Polish Thomist Review”), „Przegląd Biblijny”(“Bible Review”), „Przegląd Homiletyczny” ("Homiletic Review”), „Przegląd Teologiczny” (“Theological Review”). A lot of these reviews were written by experts on religious issues. The majority of reviews were laudatory ones, praising Polish religious literature and encouraging to further work and theological studies.
\end{abstract}

